\title{
WATER QUALITY MODELING OF AN AGRICULTURAL WATERSHED WITH BEST MANAGEMENT PRACTICES
}

\author{
Narayanan Kannan ${ }^{1}$, Nina Omani ${ }^{2}$, Roger Miranda ${ }^{3}$ \\ ${ }^{1}$ Associate Research Scientist, Texas Institute of Applied Environmental Research, Tarleton State University, \\ Stephenville, Texas, United States \\ ${ }^{2}$ Graduate Student, Biological and Agricultural Engineering, Texas A\&M University, \\ College Station, Texas, United States \\ ${ }^{3}$ Graduate Student, Lyndon B. Johnson School of Public Affairs, University of Texas at Austin, \\ Austin, Texas, United States
}

\begin{abstract}
Simulation of Best Management Practices (BMPs) affecting water quality is necessary while modeling the water quality of agricultural watersheds with BMPs in place to mitigate pollution of river. Previous studies explored methods to represent some of the water quality BMPs. However, there are still gaps in the research to represent some other BMPs such as constructed wetlands, wastewater reuse, residue management and nutrient management. This paper focuses on modeling of BMPs affecting water quality. The study area is a $1692 \mathrm{Km}^{2}$ cultivated watershed in South Texas, USA where water quality is impaired for dissolved oxygen (DO). The water quality constituents analyzed for the study are sediment, nitrogen, phosphorus, water temperature and dissolved oxygen. Apart from identification of methodology to simulate BMPs, this study estimated extent of pollution mitigation by each type of BMP. Binomial method of water quality analysis was used to judge the compliance of river reach for meeting DO criterion. This manuscript will discuss modeling of water quality constituents and the BMPs that affect water quality. In addition, the estimation of dissolved oxygen compliance of the watershed is also discussed. The results from the study indicate that the agricultural BMPs implemented in the watershed and establishment of stringer water quality criteria have in fact improved the DO trends in the tidal section of the river, which did not meet the stipulated DO criterion before.
\end{abstract}

Index Terms: Arroyo, BMP, dissolved oxygen, residue management, nutrient management, water quality

\section{INTRODUCTION}

The Arroyo Colorado watershed a sub-watershed of the Nueces-Rio Grande Coastal Basin (in United States) is located in the Lower Rio Grande Valley of South Texas and extends from near Mission, TX, eastward to the Laguna Madre. Streamflow in the Arroyo Colorado primarily is sustained by municipal and industrial effluents. Additional streamflow results from irrigation return flow, rainfallrunoff, and other point-source discharges. The Arroyo Colorado is used as a floodway, an inland waterway, and a recreational area for swimming, boating, and fishing, and is an important nursery and foraging area for shrimp, crab, and several types of marine fish.

The Texas Commission on Environmental Quality (TCEQ) has classified two reaches of the Arroyo Colorado on the basis of the physical characteristics of the stream. Segment 2201, from the port of Harlingen to the confluence with the Laguna Madre, is tidally influenced and has designated uses of contact recreation and high aquatic life. The non-tidal segment of the Arroyo Colorado, Segment 2202, has designated uses of contact recreation and intermediate aquatic life. The tidal segment of the Arroyo Colorado,
Segment 2201, has failed to meet the water-quality criteria required for its designated uses and is included on the State 303(d) list of impaired water bodies for dissolved oxygen (DO) levels below the criteria specified in the Texas Surface-Water-Quality Standards [1].

Texas AgriLife Research in co-operation with Texas State Soil and Water Conservation Board (TSSWCB) and TCEQ, began a study in 2008 to simulate the flow and the water quality of selected constituents in the Arroyo Colorado. The specific objectives of the study were to (1) Develop a computer based watershed model setup of the Arroyo Colorado that would allow representation of different BMPs adopted by growers in the watershed; (2) calibrate and validate a set of process related model parameters with available streamflow and water-quality data for the watershed and (3) Develop a suite of BMPs for changing land cover conditions, which, when progressively implemented in the watershed would bring the water quality to compliance. This manuscript will cover the modeling of water quality constituents including DO and the agricultural BMPs that affect water quality. 


\section{METHODS}

\subsection{Study Area}

The study area Arroyo Colorado watershed is located in the Lower Rio Grande Valley of South Texas in parts of Hidalgo, Cameron and Willacy counties (Fig. 1). It is a subwatershed of the Nueces-Rio Grande Coastal Basin, also known as the South (Lower) Laguna Madre Watershed (Hydrologic Unit Code 12110208). It is a $1692 \mathrm{Km}^{2}$ agricultural watershed with intensive cultivation. Most of the cultivated area receives irrigation from Rio Grande River through a network of canals, ditches and pipes under a system of irrigation districts. Irrigation practices consist of flooding fields with a specified depth of water during periods of insufficient precipitation to produce desired crop yields. Perennial stream flow in the Arroyo Colorado is primarily sustained by effluent from municipal wastewater treatment plants. Irrigation return flow and point-source discharges supplement the flow on a seasonal basis. The Arroyo Colorado is used as a floodway, an inland waterway, and a recreational area for swimming, boating, and fishing, and is an important nursery and foraging area for numerous marine species. Urbanization is extensive in the areas directly adjacent to the main stem of the Arroyo Colorado, particularly in the western and central parts of the basin. Principal urban areas include the cities of Mission, McAllen, Pharr, Donna, Weslaco, Mercedes, Harlingen, and San Benito [2-4].

(a)
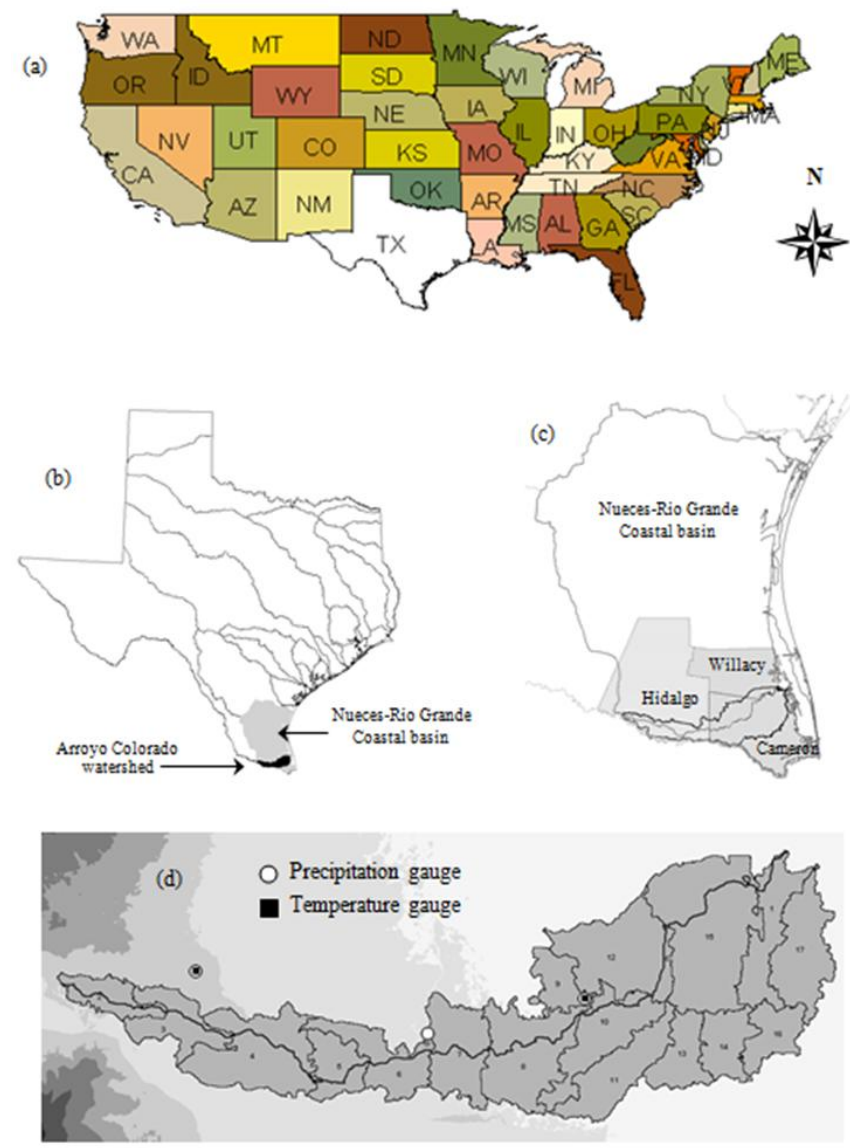

Fig -1: Location of study area
The most dominant land cover category in the watershed is agriculture $(54 \%)$ and the main crops cultivated are grain sorghum, cotton, sugar cane and citrus although some vegetable and fruit crops are also raised. About $47 \%$ of the cultivated area (including Citrus and Sugarcane) is irrigated. The irrigated area accounts for $27.5 \%$ of the watershed. The watershed soils are clays, clay loams, and sandy loams. The major soil series comprise the Harlingen, Hidalgo, Mercedes, Raymondville, Rio Grande, and Willacy [5]. Most soil depths range from about 1600 to $2000 \mathrm{~mm}$.

The mean annual temperature of the watershed is 22.7 degrees Celsius $\left({ }^{\circ} \mathrm{C}\right)$ with mean monthly temperatures ranging from $14.5{ }^{\circ} \mathrm{C}$ in January to $28.9{ }^{\circ} \mathrm{C}$ in July. Mean annual precipitation ranges from about 530 to $680 \mathrm{~mm}$, generally from west to east, in the basin [6]. Most of the annual precipitation results from frontal storms and tropical storms.

\subsection{Description of simulation model}

The Soil and Water Assessment Tool (SWAT) [7] is a conceptual continuous simulation model developed to quantify the impact of land management practices on surface water quality in large, watersheds [8-10]. It provides a continuous simulation of processes such as evapotranspiration, surface runoff, percolation, return flow, groundwater flow, channel transmission losses, pond and reservoir storage, channel routing, field drainage, crop growth and material transfers (soil erosion, nutrient and organic chemical transport and fate). The model can be run with a daily time step, although sub-daily model run is possible with Green and Ampt infiltration method. It incorporates the combined and interacting effects of weather and land management (e.g. irrigation, planting and harvesting operations and the application of fertilizers, pesticides or other inputs). SWAT divides the watershed into sub-watersheds using topography. Each sub-watershed is divided into hydrological response units (HRUs), which are unique combinations of soil and land cover. Although individual HRU's are simulated independently from one another, predicted water and material flows are routed within the channel network, which allows for large watersheds with hundreds or even thousands of HRUs to be simulated.

\subsection{Observations used}

Seven years (2000-2006) of precipitation, air temperatures, and stream flow, were used for flow calibration and validation. Precipitation data from three stations were used; temperature data from two stations were used (Fig. 1). The weather data was obtained from Texas State Climatologist Office located at Texas A\&M University at College Station. Stream flow data for two stations were obtained from International Boundary and Water Commission one near Llano Grande at FM 1015 south of Weslaco (G1) and the other near US 77 in South West Harlingen (G2) (Table 1). There are 21 permitted dischargers in the Arroyo Colorado 
Basin, 16 are municipal, 3 are industrial, and 2 are shrimp farms. The discharge permit limits of the municipal plants range from 1.5 to 37.8 million liters per day ( 0.4 to 10 million gallons per day). The shrimp farms discharge infrequently [2].

Table -1: Water quality data availability for Arroyo Colorado watershed

\begin{tabular}{|c|c|c|c|}
\hline \multirow[b]{2}{*}{ Parameter } & \multicolumn{3}{|c|}{ Data Availability } \\
\hline & $\begin{array}{c}\text { Near Llano } \\
\text { Grande at } \\
\text { FM } 1015 \\
\text { south of } \\
\text { Weslaco }\end{array}$ & $\begin{array}{c}\text { Near US } 77 \\
\text { in South } \\
\text { West } \\
\text { Harlingen }\end{array}$ & $\begin{array}{c}\text { Port of } \\
\text { Harlingen }\end{array}$ \\
\hline Stream flow & Available & Available & \\
\hline $\begin{array}{l}\text { Suspended } \\
\text { sediment }\end{array}$ & Available & Available & Available* \\
\hline Total Nitrogen & & Available & \\
\hline $\begin{array}{l}\text { Nitrate } \\
\text { Nitrogen }\end{array}$ & & Available & \\
\hline $\begin{array}{l}\text { Ammonia } \\
\text { Nitrogen }\end{array}$ & Available & Available & Available \\
\hline $\begin{array}{l}\text { Total } \\
\text { Phosphorus }\end{array}$ & & Available & \\
\hline Orthophosphate & & Available & \\
\hline $\begin{array}{l}\text { Dissolved } \\
\text { Oxygen }\end{array}$ & & Available & \\
\hline $\begin{array}{l}\text { Water } \\
\text { Temperature }\end{array}$ & & Available & Available $^{*}$ \\
\hline
\end{tabular}

* Very few samples; not considered for calibration

Water quality data from limited grab samples were obtained for suspended sediment (SS), nitrogen (ammonia nitrogen (amm $\mathrm{N}$, nitrate nitrogen $\left(\mathrm{NO}_{3} \mathrm{~N}\right)$ and total nitrogen $(\mathrm{TN})$ ), phosphorus (ortho phosphorus (OP) and total phosphorus (TP)), water temperature (WT) and dissolved oxygen (DO). Data were available from 3 stations viz. near Weslaco, near Harlingen and the third near Port of Harlingen (Table 1). Out of the three stations, only the station near Harlingen had data for all the water quality variables. The gauge near Weslaco had flow, SS and amm N only. However, the gauge near Port of Harlingen had very limited data $(<10-20$ observations only) for SS, amm N, and WT and therefore not used for the analysis. (Table 1). The observations were available in the form of concentrations (except water temperature). They were eventually converted to loads by multiplying them with daily flow rather than instantaneous flow (instantaneous flow is generally not available with all the WQ observations).

The monitored observations (concentrations) were converted to time series of loads using a continuous time series of flow (typically daily stream flow). There are computer programs to accomplish this. They convert flow and concentrations using regression and statistical techniques. They also estimate uncertainties of estimates. One such program is
LOAD ESTimator (LOADEST) developed by United States Geological Survey (USGS) [11]. In LOADEST, data variables such as various functions of flow, time and some other user-specified variables can be included. The program develops a regression model for estimation of load after calibration. The regression model, once formulated is then used to estimate loads for a user-specified time frame. LOADEST estimates mean load estimates, standard errors and $95 \%$ confidence intervals developed on a monthly or seasonal basis. LOADEST output includes diagnostic tests and warnings to the user in determining correct estimation procedure and ways to interpret the information obtained. The time series of pollutants estimated this way using LOADEST based on grab sample pollutant concentrations and flow is referred to as observations throughout this article.

\subsection{Model setup of watershed}

ArcSWAT interface was used for preparing the SWAT model setup of Arroyo Colorado. For delineation of watershed boundary, 30-m USGS DEM was used. A digitized stream network and a watershed boundary from the previous HSPF modeling study [2] were used as supporting information for the delineation of watershed and stream network for the present study. The watershed was eventually discretized into 17 sub-watersheds.

Spatial Sciences Lab of Texas A\&M University at College Station, based on satellite data and a field survey, prepared the land cover map. The map incorporates the present land cover conditions (2004-2007) in the watershed. Crop rotation, irrigation, and dates of planting are also available with the land use map on a farm/field basis. The dominant land cover categories in the watershed are agriculture (54 $\%)$, range $(18.5 \%)$, urban $(12.5 \%)$, water bodies $(6 \%)$ and sugarcane $(4 \%)$ although some vegetable and fruit crops are also raised. The SSURGO soil map was downloaded from USDA-NRCS for Cameron, Willacy and Hidalgo counties. The soil properties associated with a particular soil type is derived using the SSURGO soil database tool. 475 HRUs were delineated based on a combination of land use and soil. In the present delineation, areas as small as 9.1 ha $(22.5$ acres) are represented as HRUs.

Dates of planting were obtained from the land use map. The durations of crops were obtained from crop fact sheets from Texas A\&M extension publications based on which the tentative harvest dates are identified for each crop [12-17]. Dates of harvest collected during our visits to the watershed were used along with the above information. Typically there are two tillage operations (in conventional tillage) for each crop, one soon after the harvest of the previous crop and the other midway between the harvest of the previous crop and the planting of the present crop. In conservation tillage one tillage operation (mostly soon after harvest of the previous crop) or no tillage operation is performed (Andy Garza, Texas State Soil and Water Conservation Board, Harlingen, personal communication). All the management operations such as tillage, planting and harvest were scheduled on non- 
rainy days (In reality these operations were less likely to have happened on rainy days). Irrigation of crops will be discussed in the subsequent sections of the paper.

\subsection{Modeling Best Management Practices (BMPs)}

\subsubsection{Modeling irrigation of crops and irrigation BMPs}

Tentative quantity, timing and frequency of irrigation required for major crops (such as sorghum, cotton and sugar cane) were obtained from NRCS and TSSWCB staff in the watershed. Crop fact sheets published by Texas A\&M AgriLife Extension were also collected to estimate the irrigation information for the crops [12-19]. To model canal irrigation, the following procedure is used. Land cover map, soil map and sub-basin map were overlaid using GIS tools and a comprehensive map is prepared that has all three's information (HRU information). An HRU under agriculture land cover can be either irrigated or not irrigated. If irrigated, the model will follow the canal irrigation procedure. Information on Irrigation Districts for the study area is available in the form of a map from the Irrigation Technology Center, Texas A\&M University [20]. In addition, the average water conveyance efficiency for each irrigation district is available separately [21]. This information was combined and merged with the HRU map to identify the irrigation district that comes under each HRU. This has conveyance efficiency information for each HRU. For this study, conveyance efficiency includes all loses in the irrigation distribution system from water diversion river to field. Conveyance efficiency combined with depth of water application for each irrigation event for each crop allowed us to estimate the tentative quantity of water that could have been diverted from the source for irrigating the crop. For estimating depth, duration and frequency of irrigation, several publications/reports were referenced, and thus, critical crop growth stages at which irrigation is essential were estimated. For scheduling irrigation in the model setup, the timings were estimated based on probable days of irrigation (identified by looking at the daily water stress values reported by the model for the simulation that involves no irrigation event for any crop in any HRU), and the critical crop growth stages requiring irrigation were used as reported in the literature/field data. There are four different types of irrigation BMPs used in the model setup. Two irrigation BMPs namely Irrigation Water Conveyance, Pipeline and Irrigation system-surface surge valves are modeled as water savers rather than physical changes in irrigation appurtenances. Land leveling is modeled by changing model parameters and water management by changes in frequency and timing and magnitude of irrigation with respect to cumulative precipitation.

\subsubsection{Conservation Crop Rotation (NRCS practice code} 328)

This BMP implies growing high residue producing crops that produce a minimum of $2800 \mathrm{~kg} / \mathrm{ha} / \mathrm{year}(2500$ $\mathrm{lbs} / \mathrm{ac} / \mathrm{year}$ ) of residue for a minimum of 1 year within a given two year period. Corn and Grain Sorghum are examples for high residue producing crops. Sorghum is the dominant crop in cultivated areas of the watershed. Corn is also cultivated in some areas. The crop rotation in the watershed has Sorghum, or Corn as per the abovementioned conditions prescribed for conservation crop rotation. Therefore, no changes were made in the watershed model set up to represent this BMP [22].

\subsubsection{Nutrient Management (NRCS practice code 590)}

Nutrient Management represents managing fertilizer quantity, placement, and timing based on realistic yield goals, and moisture prospects. Under this BMP, fertilizer should be applied in split applications throughout the year (early March, late May, late August, and mid-October) prior to irrigation or forecasted rain to maximize the use of the fertilizer and minimize the leaching potential. Nitrogen applications will not exceed $112 \mathrm{~kg} / \mathrm{ha}(100 \mathrm{lb} / \mathrm{ac})$ of total nitrogen per application. Specific nutrient recommendations will be given by NRCS when a soil analysis report is provided. A soil analysis is taken a minimum of once every third year by the land owner/renter beginning with the year that the plan or contract is signed. Nutrient management is mimicked in the model as given below.

Table -2: Fertilizer rates for different crops under nutrient management and non-nutrient management

\begin{tabular}{|l|r|r|r|r|}
\hline \multirow{2}{*}{ Crop } & \multicolumn{2}{|c|}{ Nitrogen (kg/ha) } & \multicolumn{2}{c|}{ Phosphorus (kg/ha) } \\
\cline { 2 - 5 } & Regular & $\begin{array}{c}\text { Nutrient } \\
\text { Manage- } \\
\text { ment }\end{array}$ & Regular & $\begin{array}{c}\text { Nutrient } \\
\text { Manage- } \\
\text { ment }\end{array}$ \\
\hline Sorghum & 160 & 152 & 69 & 55 \\
\hline Cotton & 150 & 125 & 68 & 34 \\
\hline Sugarcane & 224 & 216 & 0 & 0 \\
\hline
\end{tabular}

The fertilizer applications for cultivated fields were already modeled in terms of 2 or 3 split applications. For the HRUs that come under this BMP, the split applications were strictly followed as per the guidelines suggested in the BMP practice code. In addition, the initial amount of $\mathrm{N}$ and $\mathrm{P}$ present in the soil were deducted from the recommended regular fertilizer application rates for different crops (to mimic soil-survey based $\mathrm{N}$ and $\mathrm{P}$ recommendations). Realistic initial $\mathrm{N}$ and $\mathrm{P}$ rates were obtained by using the final amount of $\mathrm{N}$ and $\mathrm{P}$ remaining in the soil (as reported by the model) after several years of model runs. With respect to recommended regular rates of $\mathrm{N}$ and $\mathrm{P}$, less proportion of $\mathrm{P}$ is applied than $\mathrm{N}$ under nutrient management scenario. This is because Phosphorus is less likely to leach from soil and more available. A comparison of $\mathrm{N}$ and $\mathrm{P}$ rates for different crops with and without nutrient management is given in Table 2 . 


\subsubsection{Residue Management (NRCS practice code 329b)}

Residue Management-Mulch-till is managing the amount, orientation, and distribution of crop and other plant residue on the soil surface year round while growing crops. The entire field surface is tilled prior to the planting operation. Sometimes the residue is partially incorporated using chisels, sweeps, field cultivators, or similar implements. This BMP is practiced as a part of a conservation management to achieve some/all of the following: reduce sheet and rill erosion, reduce wind erosion, maintain or improve soil organic matter content, conserve soil moisture, and provide food and escape cover for wildlife [23]. This BMP was modeled by harvesting only the crop (no killing of crop; harvesting only the useful yield), and leaving the residue (non-yield portion of crop) until the planting of next crop.

\subsubsection{Seasonal Residue Management (NRCS practice code 344)}

This is very similar to residue management. This BMP implies leaving protective amounts of crop residue (30\% ground cover/1,360 $\mathrm{kg}(3,000 \mathrm{lbs})$ minimum) on the soil surface through the critical eroding period (Dec. 15 to Jan 1 or six weeks prior to planting) to reduce wind and water erosion during the raising of a high-residue crop. In the event that a low residue crop is being produced, the residue requirements are not met and soil begins to blow, emergency tillage operations will be performed. Similar to residue management, this BMP was modeled by harvesting only the crop (no killing of crop; harvesting only the useful yield) and leaving the residue (non-yield portion of crop). However, this can happen only during critical eroding period or until 6 weeks prior to the planting of next crop.

\subsubsection{Terrace (NRCS Practice Code 600)}

Terraces are broad earthen embankments constructed across slope to intercept runoff and control water erosion. They are intended for both erosion control and water management. Terraces decrease hill slope length, prevent formation of gullies, and intercept, retain, and conduct runoff to a safe outlet and therefore reduce the concentration of sediment in water. Terraces increase the amount of water available for recharging the shallow aquifers by retaining runoff [24]. In this study, terraces are represented in the model by decreasing curve number $(\mathrm{CN})$, reducing Universal Soil Loss Equation (USLE) conservation support practice factor ( $\mathrm{P}$ factor) and decreasing slope length. Terraces are not one of the common BMPs in the watershed.

\subsubsection{Constructed Wetlands}

Constructed wetlands are of two types 1) free water surface systems (FWS) with shallow water depth and 2) subsurface flow systems with water flowing laterally through the sand or gravel. In general, constructed wetlands are very effective in removing suspended solids. Nitrogen removal occurs mostly in the form of ammonia $\left(\mathrm{NH}_{3}\right)$ with dominating nitrification/denitrification process. Because of the shallow depth and access to soil, the phosphorus removal is relatively higher for constructed wetlands than natural wetlands. The bacteria attached to plant stems and humic deposits help in considerable removal of $\mathrm{BOD}_{5}$. Typical pollutant removal ability of wetlands is available in a report published by USEPA [25]. For the study area, the probable pollutant removal efficiencies are obtained from the USEPA report based on wastewater inflow to the wetland. For representing the existing constructed wetlands in the watershed, the pollutants discharge from wastewater treatment plants (point source discharge data in the model setup) is discounted based on the typical pollutant removal efficiency estimated from the EPA report. The typical pollutant removal efficiencies used in the model setup to represent constructed wetlands are shown in Table 3. The constructed wetlands in the Arroyo Colorado watershed are assumed to be of FWS type. Effluent polishing ponds were aggregated at sub-basin level, and pollutants from point source data were discounted using typical values shown in [4]. The total area of each BMP present in the watershed and that represented in the model are shown in Table 4.

Table -3: Typical pollutant removal efficiencies used for representing constructed wetlands

\begin{tabular}{|l|l|l|l|l|l|l|}
\hline \multirow{2}{*}{ Sub-basin } & \multirow{2}{*}{$\begin{array}{c}\text { Effluent } \\
\text { inflow } \\
\left(\mathrm{m}^{3} / \text { day) }\right.\end{array}$} & \multicolumn{5}{|c|}{ \% removal of } \\
\cline { 3 - 7 } & & $\mathrm{SS}$ & $\mathrm{NH}_{3} \mathrm{~N}$ & $\mathrm{NO}_{3} \mathrm{~N}$ & $\mathrm{TDP}$ & $\mathrm{BOD}$ \\
\hline $\begin{array}{l}\text { La Feria (Sub- } \\
\text { basin 8) }\end{array}$ & 972.7 & 86 & 64.5 & 20 & 71 & 64 \\
\hline $\begin{array}{l}\text { San Benito } \\
\text { (Sub-basin 10) }\end{array}$ & $9,621.5$ & 28 & 64.5 & 20 & 71 & 64 \\
\hline
\end{tabular}

\subsubsection{Wastewater Reuse}

This BMP implies using wastewater for irrigation with the goal of reducing point source nutrient loads to the river. To represent wastewater reuse in the model, quantity of wastewater used and location from which the wastewater is taken needed to be known. This information is available for the Arroyo Colorado from the Arroyo Colorado Watershed Protection Plan [4]. In the model, point source flow is discounted in proportion to the wastewater reuse intended from the effluent discharge facilities. The discounted water is then added to the irrigation water in the sub-basin. The quantity of nutrients associated with the quantity of reuse is estimated and applied as manure in the same HRU where the irrigation operation was defined. Any sediment associated with the wastewater was not accounted/discounted because the quantity was negligible.

As much as possible the extents of different BMPs in the watershed were represented reasonably well in the model setup. The difference in areas between what is existing in the field and what is represented in the model are minimal for each BMP (Table 4). 
Table -4: Representation of different BMPs in the watershed model setup

\begin{tabular}{|l|r|r|r|}
\hline \multicolumn{1}{|c|}{$\begin{array}{c}\text { Best Management } \\
\text { Practice }\end{array}$} & $\begin{array}{c}\text { Total } \\
\text { area of } \\
\text { BMP } \\
\text { (acres) }\end{array}$ & $\begin{array}{c}\text { Area of } \\
\text { BMP } \\
\text { modeled } \\
\text { (acres) }\end{array}$ & $\begin{array}{c}\text { \% Error at } \\
\text { watershed } \\
\text { level }\end{array}$ \\
\hline $\begin{array}{l}\text { Conservation crop } \\
\text { rotation }\end{array}$ & $20,910.8$ & $21,627.3$ & 3.4 \\
\hline Irrigation land leveling & $12,185.3$ & $12,455.8$ & 2.2 \\
\hline $\begin{array}{l}\text { Irrigation system- } \\
\text { Sprinkler-New }\end{array}$ & 396.4 & 417.9 & 5.4 \\
\hline $\begin{array}{l}\text { Irrigation wystem- } \\
\text { Surge valves }\end{array}$ & $22,931.6$ & $22,636.2$ & -1.3 \\
\hline $\begin{array}{l}\text { Irrigation water } \\
\text { conveyance, Pipeline }\end{array}$ & $10,470.3$ & $10,750.6$ & 2.7 \\
\hline $\begin{array}{l}\text { Irrigation } \\
\text { management }\end{array}$ & $23,724.3$ & $24,132.3$ & 1.7 \\
\hline Nutrient management & $12,053.8$ & $11,838.9$ & -1.8 \\
\hline $\begin{array}{l}\text { Pasture and Hay } \\
\text { planting }\end{array}$ & 952.3 & 805.1 & -15.5 \\
\hline Prescribed grazing & 961.0 & 955.2 & -0.6 \\
\hline Residue management & $1,417.1$ & $1,313.9$ & -7.3 \\
\hline $\begin{array}{l}\text { Residue management- } \\
\text { seasonal }\end{array}$ & $19,357.2$ & $20,654.0$ & 6.7 \\
\hline Subsurface drain & $4,327.6$ & $4,232.3$ & -10.8 \\
\hline Terrace & 130.7 & 116.5 & \\
\hline
\end{tabular}

\subsection{Calibration}

Calibration of the chosen model and a subsequent validation are necessary to have confidence that the model gives reliable and useful results, and it is worthy to use it to do scenario trials. For the Arroyo Colorado watershed modeling study, the SWAT model was calibrated and validated for flow, sediment, nitrogen (nitrate, ammonia and total nitrogen), phosphorus (total phosphorus and orthophosphate), water temperature and dissolved oxygen. The model was run at a daily time step from 1999-2010, and the results were aggregated at monthly time steps for the purpose of calibration. Flow calibration was carried out at both monthly (Table 2 and Table 3) and daily time steps. Data from 1999 is used for model warm-up to make state variables assume realistic initial values. Data from 20002003 is used for calibration and 2004-2006 for validation (Table 2 and Table 3). However, the model was run until 2010. More details on flow calibration can be found in [22] and [26]. SWAT-CUP [27] was used for sensitivity analysis and flow calibration.

The availability of water quality observations was not as good as flow. Therefore, a separate split sample calibration and validation was not carried out. Instead, the observations available from 2000-2009 (Table 1) were used to verify whether the model gives reasonable results in terms of magnitude, pattern and timing for different water quality constituents.

Data for sediment calibration is available for three stations namely near Weslaco, near Harlingen and port of Harlingen respectively. However, the port of Harlingen gauge had very few monitored observations and therefore it was not used for calibration-validation. Model parameters affecting soil erosion and sediment yield at watershed, river reach and HRU level (Table 4) were adjusted to match the predicted sediment yield with that of observations. Only sensitive parameters were included for calibration.

Table -5: Model parameters used for sediment calibration

\begin{tabular}{|c|c|c|c|c|}
\hline \multirow[t]{2}{*}{ Parameter } & \multirow[t]{2}{*}{ Definition } & \multirow{2}{*}{$\begin{array}{l}\text { Spatial } \\
\text { scale }\end{array}$} & \multicolumn{2}{|c|}{$\begin{array}{l}\text { Range of } \\
\text { values }\end{array}$} \\
\hline & & & Min & $\operatorname{Max}$ \\
\hline $\begin{array}{l}\text { ADJ_PKR } \\
\text { AD_P }\end{array}$ & $\begin{array}{l}\text { Flow peak rate } \\
\text { adjustment factor } \\
\text { for sediment routing } \\
\text { in tributaries }\end{array}$ & $\begin{array}{l}\text { Water- } \\
\text { shed }\end{array}$ & 0.0 & 1.0 \\
\hline PRF & $\begin{array}{l}\begin{array}{l}\text { Peak rate } \\
\text { adjustment factor } \\
\text { for sediment routing } \\
\text { in main channel }\end{array} \\
\text { fann }\end{array}$ & $\begin{array}{l}\text { Water- } \\
\text { shed }\end{array}$ & 0.0 & 1.0 \\
\hline SPCON & $\begin{array}{l}\text { Linear parameter } \\
\text { controlling sediment } \\
\text { re-entrained in } \\
\text { channels }\end{array}$ & $\begin{array}{l}\text { Water- } \\
\text { shed }\end{array}$ & $\begin{array}{l}0.000 \\
1\end{array}$ & 0.01 \\
\hline SPEXP & $\begin{array}{l}\text { An exponent } \\
\text { controlling sediment } \\
\text { re-entrained in } \\
\text { channels }\end{array}$ & $\begin{array}{l}\text { Water- } \\
\text { shed }\end{array}$ & 1.0 & 2.0 \\
\hline CH_N2 & $\begin{array}{l}\text { Manning's } \\
\text { roughness value for } \\
\text { the main channel }\end{array}$ & Reach & 0.016 & 0.15 \\
\hline CH_COV1 & $\begin{array}{l}\text { Channel erodibility } \\
\text { factor }\end{array}$ & Reach & 0.0 & 1.0 \\
\hline CH_COV2 & $\begin{array}{l}\text { Channel cover } \\
\text { factor }\end{array}$ & Reach & 0.0 & 1.0 \\
\hline CH_N1 & $\begin{array}{l}\text { Manning roughness } \\
\text { value for the } \\
\text { tributary channels }\end{array}$ & $\begin{array}{l}\text { Sub- } \\
\text { basin }\end{array}$ & 0.025 & 0.15 \\
\hline Erosion $\mathrm{K}$ & $\begin{array}{l}\text { Soil erodibility } \\
\text { factor }\end{array}$ & HRU & 0.0 & 1.0 \\
\hline LAT_SED & $\begin{array}{l}\text { Sediment } \\
\text { concentration in } \\
\text { lateral flow }(\mathrm{mg} / \mathrm{L})\end{array}$ & HRU & 0.0 & -- \\
\hline
\end{tabular}

A good set of monitored nutrient data was available for the gauge near Harlingen. For the other gauge near Mercedes only ammonia nitrogen was available (Table 1). Similar to flow and sediment, a sensitivity analysis was conducted to identify the most sensitive parameters to be included in the calibration. The parameters operate at different spatial scales in the watershed namely watershed, river reach and HRU (Tables 5 and 6). The parameters were adjusted within the upper and lower bounds. Calibration was not carried out for 
dissolved oxygen because the results were reasonable without any calibration.

Table -6: Model parameters and their range considered for nutrient calibration

\begin{tabular}{|c|c|c|c|c|}
\hline \multirow[t]{2}{*}{ Parameter } & \multirow[t]{2}{*}{ Definition } & \multirow{2}{*}{$\begin{array}{l}\text { Spatial } \\
\text { scale }\end{array}$} & \multicolumn{2}{|c|}{$\begin{array}{l}\text { Range of } \\
\text { values }\end{array}$} \\
\hline & & & Min & Max \\
\hline N_UPDIS & $\begin{array}{ll}\text { Nitrogen uptake } \\
\text { distribution } \\
\text { parameter }\end{array}$ & $\begin{array}{l}\text { Water- } \\
\text { shed }\end{array}$ & 0.0 & 40.0 \\
\hline P_UPDIS & $\begin{array}{l}\text { Phosphorus uptake } \\
\text { distribution } \\
\text { parameter }\end{array}$ & $\begin{array}{l}\text { Water- } \\
\text { shed }\end{array}$ & 0.0 & 40.0 \\
\hline NPERCO & $\begin{array}{l}\text { Nitrogen } \\
\text { percolation } \\
\text { coefficient } \\
\end{array}$ & $\begin{array}{l}\text { Water- } \\
\text { shed }\end{array}$ & 0.01 & 1.0 \\
\hline PPERCO & $\begin{array}{l}\text { Phosphorus } \\
\text { percolation } \\
\text { coefficient } \\
\end{array}$ & $\begin{array}{l}\text { Water- } \\
\text { shed }\end{array}$ & 10.0 & 17.5 \\
\hline PHOSKD & $\begin{array}{ll}\text { Phosphorus } & \text { soil } \\
\text { partitioning } & \\
\text { coefficient } & \\
\end{array}$ & $\begin{array}{l}\text { Water- } \\
\text { shed }\end{array}$ & 0.01 & 300 \\
\hline PSP & $\begin{array}{l}\text { Phosphorus sorption } \\
\text { coefficient }\end{array}$ & $\begin{array}{l}\text { Water- } \\
\text { shed }\end{array}$ & 0.0 & 1.0 \\
\hline RS2 & $\begin{array}{l}\text { Benthic source rate } \\
\text { for dissolved } \\
\text { phosphorus }\end{array}$ & Reach & 0.001 & 0.1 \\
\hline RS3 & $\begin{array}{l}\text { Benthic source rate } \\
\text { for } \\
\text { nitrogen }\end{array}$ & Reach & 0.001 & 0.1 \\
\hline RS4 & $\begin{array}{l}\text { Rate coefficient for } \\
\text { organic nitrogen } \\
\text { settling }\end{array}$ & Reach & 0.001 & 0.1 \\
\hline RS5 & $\begin{array}{l}\text { Rate coefficient for } \\
\text { organic phosphorus } \\
\text { settling }\end{array}$ & Reach & 0.001 & 0.1 \\
\hline $\mathrm{BC} 1$ & $\begin{array}{l}\text { Rate constant for } \\
\text { biological oxidation } \\
\text { of ammonia to } \\
\text { nitrite }\end{array}$ & Reach & 0.1 & 1.0 \\
\hline $\mathrm{BC} 2$ & $\begin{array}{l}\text { Rate constant for } \\
\text { biological oxidation } \\
\text { of nitrite to nitrate }\end{array}$ & Reach & 0.2 & 2.0 \\
\hline $\mathrm{BC} 3$ & $\begin{array}{lr}\text { Rate constant } & \text { for } \\
\text { hydrolysis } & \text { of } \\
\text { organic nitrogen } & \text { to } \\
\text { ammonia } & \end{array}$ & Reach & 0.2 & 0.4 \\
\hline BC4 & $\begin{array}{l}\text { Rate constant for } \\
\text { mineralization of } \\
\text { organic phosphorus }\end{array}$ & Reach & 0.01 & 0.7 \\
\hline GWSOLP & $\begin{array}{l}\text { Concentration of } \\
\text { soluble phosphorus } \\
\text { in groundwater }\end{array}$ & HRU & 0.01 & 1.0 \\
\hline $\begin{array}{l}\text { HLIFE_ } \\
\text { NGW }\end{array}$ & $\begin{array}{l}\text { Half -life of nitrate } \\
\text { in the shallow } \\
\text { aquifer }\end{array}$ & HRU & 30.0 & 200 \\
\hline
\end{tabular}

\subsection{Binomial method of water quality analysis}

Binomial method is a probability based procedure used when the proportion of population that belongs to one of the two categories, in the present study, the compliance or noncompliance of the water body for dissolved oxygen (DO). The proportion of population that is non-compliant (DO $<4$ $\mathrm{mg} / \mathrm{L})$ is denoted as $\mathrm{p}$. Therefore, the proportion of population that is compliant (or DO > =4) is 1-p. Here, $p$ and $\mathrm{q}$ are probabilities of collecting a water quality sample that does not meet and meets the dissolved oxygen criterion respectively. The above probabilistic explanation is pertaining to a single sample or event. For multiple events involving many water quality samples, cumulative probabilities should be taken into consideration. While analyzing the water quality samples, two different types of errors are possible to encounter. They are:

a) Type 1 error: This occurs when the water body is identified as not meeting the water quality criterion when it actually meets.

b) Type 2 error: This occurs when the water body is identified as meeting the water quality criterion when it actually does not meet.

TCEQ based on many years of water quality sampling and analysis has quantified the probabilities of having type 1 and type 2 errors in DO analysis. They are $8 \%$ for type 1 error and $20 \%$ for type 2 errors. Therefore, if more than $20 \%$ of samples collected show DO $<4 \mathrm{mg} / \mathrm{L}$ then the water body will be classified as non-compliant (does not meet the stipulated DO concentration of $4 \mathrm{mg} / \mathrm{L}$ ).

A computer program was written accounting the above mentioned items to analyze the predicted dissolved oxygen concentrations from SWAT model. The results were reported as confidence (\% probability) with which the stream is meeting the dissolved oxygen criteria and the average number of days in a year when DO concentration is less than $4 \mathrm{mg} / \mathrm{L}$. More details on DO analysis is discussed in the results and discussion section.

\section{RESULTS AND DISCUSSION}

Flow calibration and validation was carried out for two gauges one near Weslaco/Mercedes and the other near Harlingen. The model is able to reproduce the flow observations very well (Fig 2 and Fig 3) in both gauges during calibration and validation periods (Tables 7 and 8). Similar results were obtained for flow at a daily time step (not shown). Model predicted results are better in calibration period than in validation period. An investigation of annual rainfall revealed that calibration period was relatively wetter (641 mm of mean annual rainfall during 2000-2003) than validation period. The model could have over -estimated the ET and therefore predicted less runoff. 


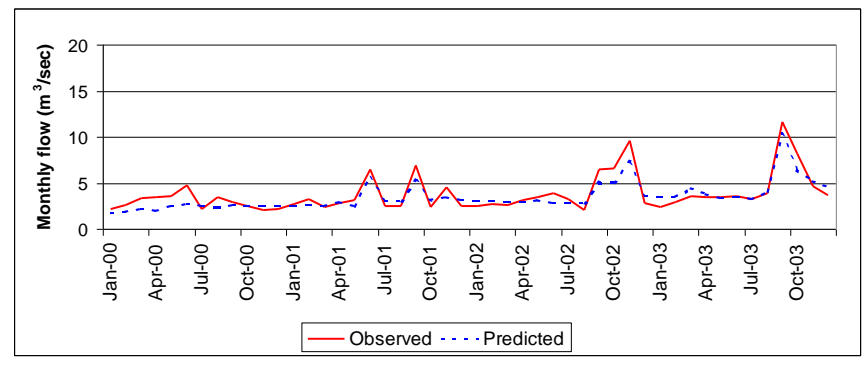

Fig -2a: Monthly flow for Arroyo Colorado near Mercedes -Calibration period

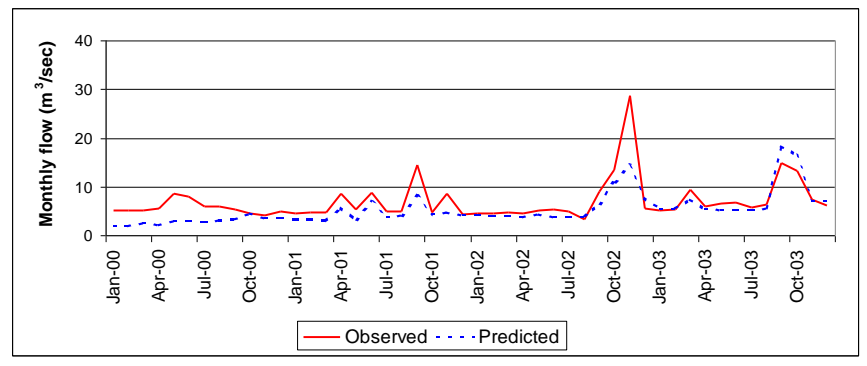

Fig -2b: Monthly flow for Arroyo Colorado near HarlingenCalibration period

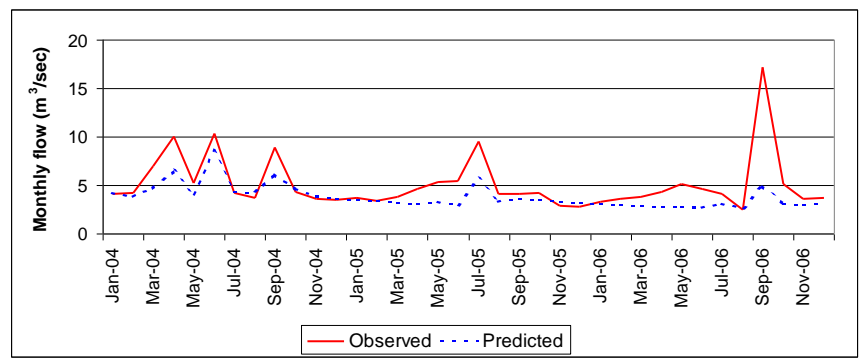

Fig -3a: Monthly flow for Arroyo near Mercedes-Validation period

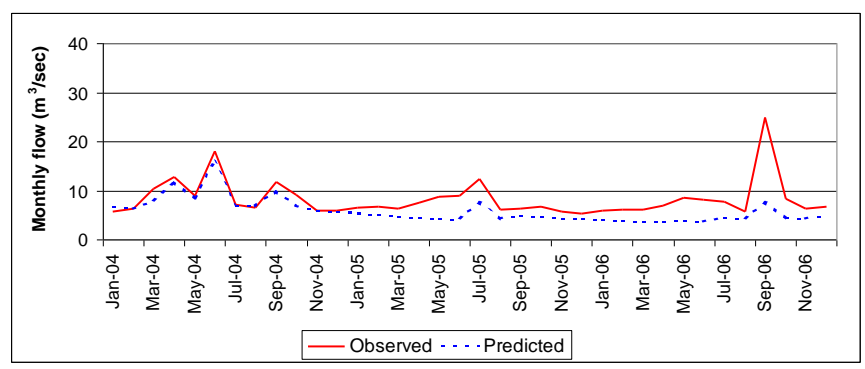

Figure -3b: Monthly flow for Arroyo near HarlingenValidation period

Table -7: Mean monthly flow results for Arroyo Colorado

\begin{tabular}{|l|l|l|l|l|}
\hline \multirow{2}{*}{$\begin{array}{c}\text { Monitoring } \\
\text { Station }\end{array}$} & \multicolumn{2}{|c|}{$\begin{array}{c}\text { Calibration period } \\
(2000-2003)\end{array}$} & \multicolumn{2}{c|}{$\begin{array}{c}\text { Validation period } \\
(2004-2006)\end{array}$} \\
\cline { 2 - 5 } & $\begin{array}{c}\text { Predicted } \\
\left(\mathrm{m}^{3} / \mathrm{sec}\right)\end{array}$ & $\begin{array}{c}\text { Observed } \\
\left(\mathrm{m}^{3} / \mathrm{sec}\right)\end{array}$ & $\begin{array}{c}\text { Predicted } \\
\left(\mathrm{m}^{3} / \mathrm{sec}\right)\end{array}$ & $\begin{array}{c}\text { Observed } \\
\left(\mathrm{m}^{3} / \mathrm{sec}\right)\end{array}$ \\
\hline $\begin{array}{l}\text { Near } \\
\text { Mercedes }\end{array}$ & 3.5 & 3.8 & 3.8 & 5.1 \\
\hline $\begin{array}{l}\text { Near } \\
\text { Harlingen }\end{array}$ & 5.2 & 6.9 & 5.8 & 8.2 \\
\hline
\end{tabular}

Table -8: Model performance evaluation-flow calibration

\begin{tabular}{|l|c|c|c|c|}
\hline \multirow{2}{*}{$\begin{array}{l}\text { Monitoring } \\
\text { Station }\end{array}$} & \multicolumn{2}{|c|}{$\begin{array}{c}\text { Calibration period } \\
(2000-2003)\end{array}$} & \multicolumn{2}{|c|}{$\begin{array}{c}\text { Validation period } \\
(2004-2006)\end{array}$} \\
\cline { 2 - 5 } & $\mathrm{R}^{2}$ & $\begin{array}{c}\text { Nash and } \\
\text { Sutcliffe } \\
\text { Efficiency } \\
(\%)\end{array}$ & $\mathrm{R}^{2}$ & $\begin{array}{c}\text { Nash and } \\
\text { Sutcliffe } \\
\text { Efficiency } \\
(\%)\end{array}$ \\
\hline $\begin{array}{l}\text { Near } \\
\text { Mercedes }\end{array}$ & 0.83 & 78.6 & 0.47 & 19.5 \\
\hline $\begin{array}{l}\text { Near } \\
\text { Harlingen }\end{array}$ & 0.59 & 43.1 & 0.41 & 1.8 \\
\hline
\end{tabular}

For sediment, the model predicted values were good when compared to observations except a couple of over-estimated peaks (Fig 4). Any reduction in peaks is possible only at the cost of under-estimation of sediment load on all other times. The over-estimation of sediment peaks has a certain pattern and they occurred during July-August. Flow is not responsible for problems in sediment peak (Fig 4). The correct reasons are not known.

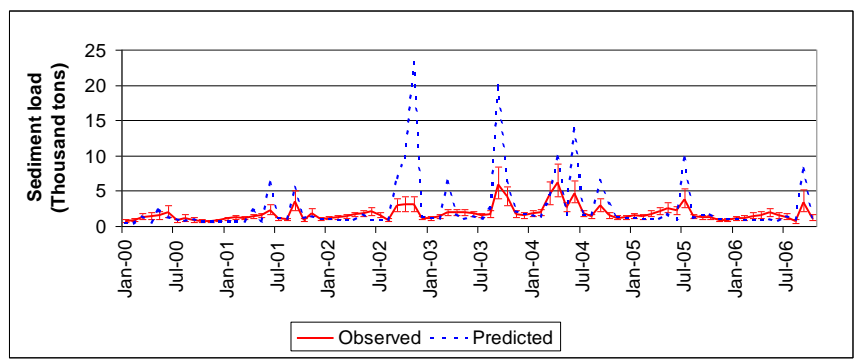

Fig -4a: Monthly sediment load for Arroyo near Mercedes

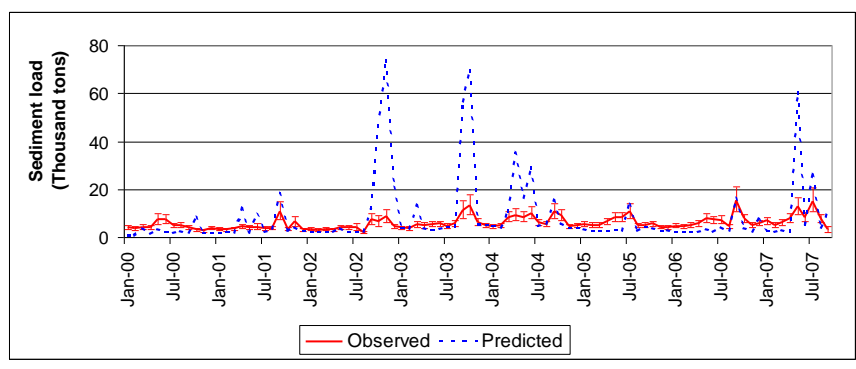

Fig -4b: Monthly sediment load for Arroyo near Harlingen

Orthophosphate was predicted well by the model for most part of the monthly time series. However, the difference between predicted and observed orthophosphate load was large during 2006-2007 (Fig 5a). Underestimation of flow is responsible for this mismatch. For total phosphorus the model was able to trace the pattern. However, there were difficulties in matching the magnitude. The predicted loads were always higher than the observed (Fig 5b). Over estimation of sediment load especially some peaks can be attributed to the over-estimation of total phosphorus, which is coming from over-estimation sediment bound phosphorus.

For nitrogen, the model predicted values were compared against observations for ammonia nitrogen, nitrate nitrogen 


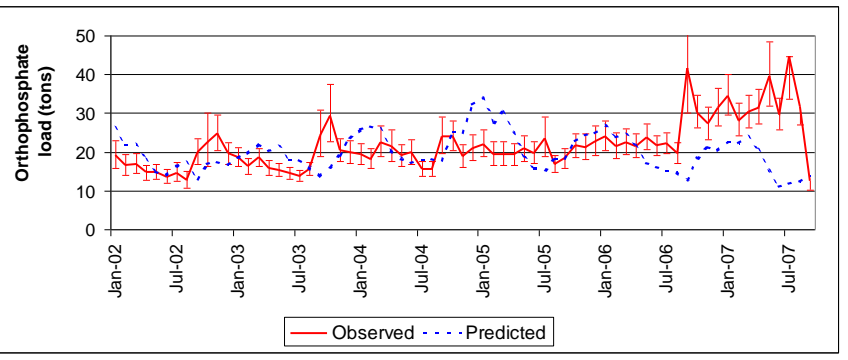

Fig -5a: Monthly Orthophosphate load for Arroyo near Harlingen

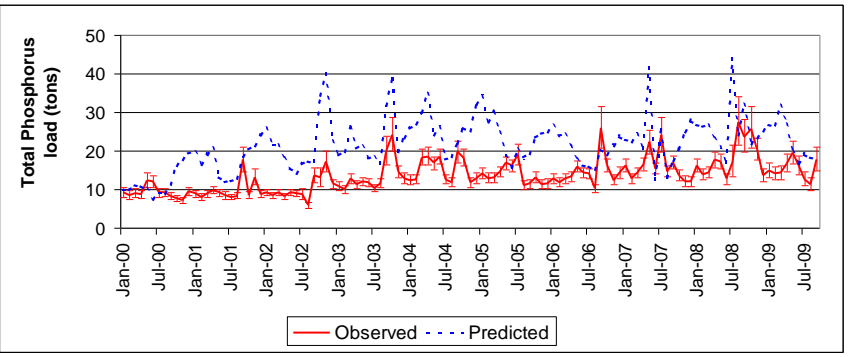

Fig -5b: Monthly total phosphorus load for Arroyo near Harlingen

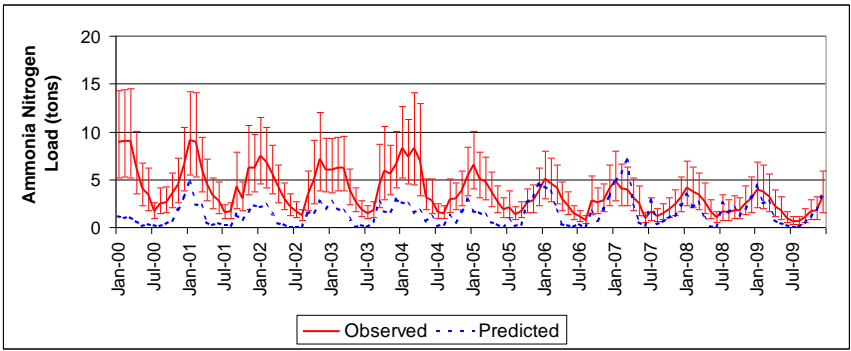

Fig -6a: Monthly ammonia nitrogen load for Arroyo near Mercedes

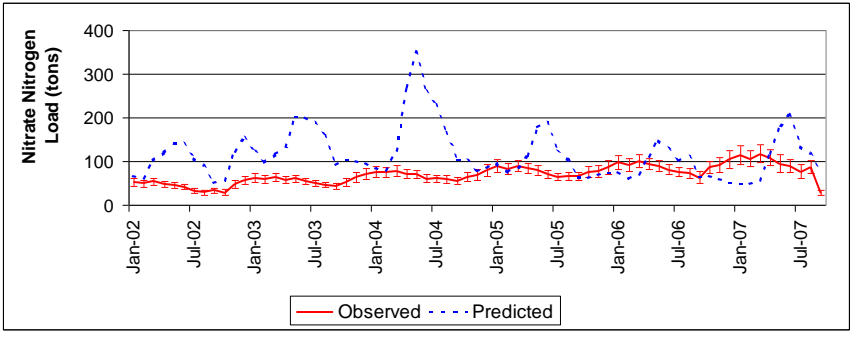

Fig -6b: Monthly nitrate nitrogen load for Arroyo near Harlingen

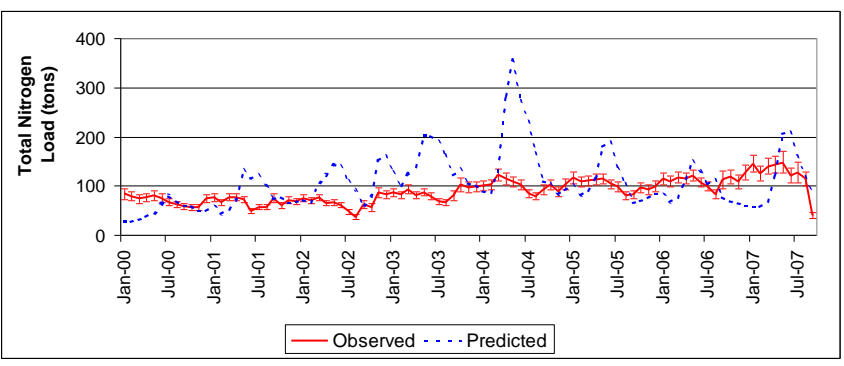

Fig -6c: Monthly total nitrogen load for Arroyo near Harlingen and total nitrogen (Fig 6). There is a close match between predictions and observations of ammonia nitrogen except for a couple of years in the beginning of the time series (Fig 6a). Underestimation of flow explains some of the reasons for underestimation of ammonia nitrogen during years 2000 and 2002. The predictions and observations of nitrate nitrogen are not matching well. The main problem exists in matching the patterns. However, the long-term average values of predicted and observed are reasonable (Fig 6b). A similar trend exists for total nitrogen predictions (Fig 6c).

For water temperature (Fig 7) and dissolved oxygen (Fig 8), no calibration was carried out. SWAT estimates water temperature as an empirical function of air temperature and therefore, no parameter is available for calibration. For dissolved oxygen, the model gave better results without any requirement for calibration (Fig 8).

Although there are some mismatches between predicted and observed water quality constituents, overall the performance of calibrated model is good (Table 9). Therefore, the model can be used for simulating scenario trials.

Table -9: Comparison of predicted and observed mean of various water quality parameters

\begin{tabular}{|c|c|c|c|c|}
\hline \multirow{2}{*}{$\begin{array}{l}\text { Parameter } \\
\quad \text { (unit) }\end{array}$} & \multicolumn{2}{|c|}{$\begin{array}{l}\text { Near Llano Grande } \\
\text { at FM } 1015 \text { south } \\
\text { of Weslaco }\end{array}$} & \multicolumn{2}{|c|}{$\begin{array}{c}\text { Near US } 77 \text { in } \\
\text { South West } \\
\text { Harlingen }\end{array}$} \\
\hline & $\begin{array}{l}\text { Predict- } \\
\text { ions }\end{array}$ & $\begin{array}{l}\text { Observa- } \\
\text { tions }\end{array}$ & $\begin{array}{l}\text { Predic- } \\
\text { tions }\end{array}$ & $\begin{array}{l}\text { Observa- } \\
\text { tions }\end{array}$ \\
\hline $\begin{array}{l}\text { Suspended } \\
\text { sediment load } \\
\text { (tons/year) }\end{array}$ & $2,634.1$ & $1,795.0$ & $8,434.0$ & $5,956.0$ \\
\hline $\begin{array}{l}\text { Ammonia } \\
\text { Nitrogen } \\
\text { (tons/year) }\end{array}$ & 1.3 & 4.2 & -- & -- \\
\hline $\begin{array}{l}\text { Nitrate } \\
\text { Nitrogen } \\
\text { (kg/day) }\end{array}$ & -- & -- & 116.0 & 69.0 \\
\hline $\begin{array}{l}\text { Total Nitrogen } \\
\text { (kg/day) }\end{array}$ & -- & -- & 107.0 & 89.0 \\
\hline $\begin{array}{l}\text { Ortho } \\
\text { Phosphorus } \\
\text { (kg/day) }\end{array}$ & -- & -- & 19.8 & 21.8 \\
\hline $\begin{array}{l}\text { Total } \\
\text { Phosphorus } \\
\text { (kg/day) }\end{array}$ & -- & -- & 21.4 & 13.5 \\
\hline $\begin{array}{l}\text { Water } \\
\text { temperature } \\
\left({ }^{\circ} \mathrm{C}\right)\end{array}$ & -- & -- & 24.6 & 25.3 \\
\hline $\begin{array}{l}\text { Dissolved } \\
\text { Oxygen }(\mathrm{mg} / \mathrm{L})\end{array}$ & -- & -- & 7.2 & 7.5 \\
\hline
\end{tabular}




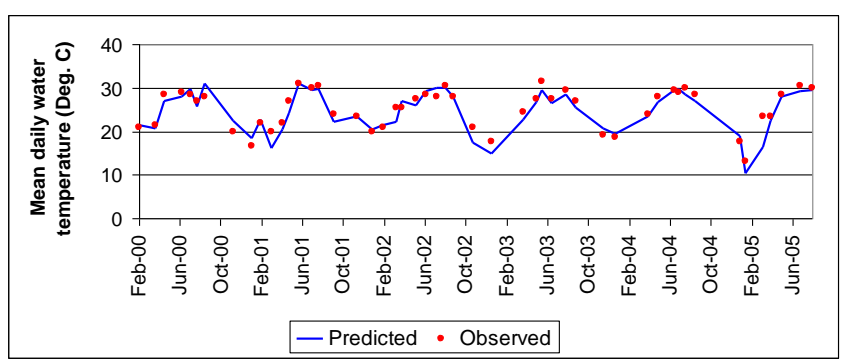

Fig -7: Mean Daily water temperature for Arroyo near Harlingen

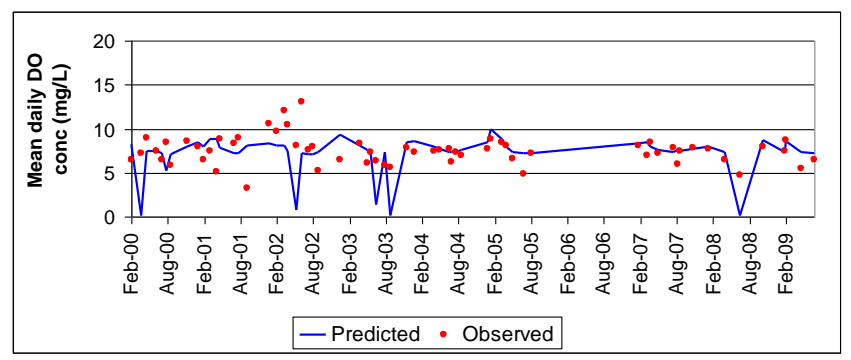

Fig -8: Mean daily dissolved oxygen for Arroyo near Harlingen

The possible pollutant load reductions in the river by implementing various BMPs in upland are presented in Table 10. Note, that not all BMPs are fully effective in controlling nutrient loads in the Arroyo Colorado. For example, tile drains when implemented for reducing water table, will transport more soluble nitrogen to the river than when there are no drains. Also, residue management is much more effective than seasonal residue management (Table 10). Therefore, care should be taken while choosing BMPs for implementation in a sub-basin. For getting most benefits from BMPs the BMPs that work best in the watershed should be implemented in places (sub-basins in the context of SWAT) where they are most needed.

The BMPs already implemented in cultivated areas of watershed have improved the water quality. This is evident from the modeled dissolved oxygen results presented in Table 11 after a binomial analysis of dissolved oxygen concentration for each reach. The watershed had DO problems in tidal reaches of watershed for which the study was carried out. Now, from table 11 (baseline model setup with existing BMPs) it can be seen that the DO compliance is achieved for all tidal reaches of the river. However, there are DO problems in non-tidal reaches (not existing in the beginning of this study) mainly coming from point source discharges arriving at reach 2 . This is getting translated to DO problems in reaches 3 and 4 also. However, it should be noted that the model is over-conservative in predicting DO concentration in reaches. It means when the model predicts high DO it is indeed high. However, whenever the DO concentration should be low the model very much underestimates the DO concentration. This is evident from the comparison of predicted and observed DO concentration plot. Therefore, care was taken while interpreting DO concentrations to translate to key decisions affecting the water quality in the watershed. In this case, nutrient loads in different reaches were analyzed together with DO scenario to arrive at important conclusions.

Table -10: Possible load reductions from different BMPs and their prioritization for implementation

\begin{tabular}{|l|l|l|l|}
\hline \multirow{2}{*}{$\begin{array}{c}\text { Best Management } \\
\text { Practice (BMP) }\end{array}$} & \multicolumn{3}{|c|}{$\begin{array}{c}\text { Load reductions obtained from } \\
\text { different BMPs (\%) }\end{array}$} \\
\cline { 2 - 4 } & $\begin{array}{c}\text { Total } \\
\text { Nitrogen }\end{array}$ & $\begin{array}{c}\text { Total } \\
\text { Phosphorus }\end{array}$ & Sediment \\
\hline $\begin{array}{l}\text { Residue } \\
\text { Management }\end{array}$ & 22.1 & 45.1 & 20.2 \\
\hline Irrigation BMPs & 11.9 & 4.3 & 3.0 \\
\hline $\begin{array}{l}\text { Nutrient } \\
\text { Management residue }\end{array}$ & 3.3 & 19.9 & 0.3 \\
\hline $\begin{array}{l}\text { Seasonal } \\
\text { management }\end{array}$ & 34.8 & -- & 4.8 \\
\hline Land leveling & 6.6 & 1.7 & 0.8 \\
\hline Tile drains & & & \\
\hline
\end{tabular}

Table -11: Modeled dissolved oxygen compliance for different reaches in the watershed

\begin{tabular}{|r|r|r|}
\hline $\begin{array}{c}\text { Reach } \\
\text { (T: Tidal } \\
\text { NT: Non-tidal) }\end{array}$ & $\begin{array}{c}\text { Confidence of } \\
\text { dissolved oxygen (DO) } \\
\text { compliance (\%) }\end{array}$ & $\begin{array}{c}\text { No of days/year } \\
\text { when } \\
\text { DO < 4mg/L }\end{array}$ \\
\hline 2 & 0 & 316 \\
3 & 0 & 237 \\
4 & 0 & 106 \\
5 & 100 & 34 \\
6 & 100 & 34 \\
7 & 100 & 24 \\
8 & 100 & 27 \\
9 & 0 & 45 \\
10 & 100 & 27 \\
11 & 0 & 226 \\
12 & 100 & 24 \\
\hline 13 & 93 & 37 \\
14 & 85 & 38 \\
15 & 100 & 22 \\
16 & 100 & 31 \\
17 & 100 & 17 \\
1 & 100 & 16 \\
\hline
\end{tabular}

\section{CONCLUSIONS}

Texas Commission for Environmental Quality along with Texas State Soil and Water Conservation Board initiated monitoring and mitigation measures. This study was intended to assess the present water quality trends in the river especially the DO, estimate how far the mitigation measures (agricultural Best Management Practices (BMPs)) have helped to bring the river under compliance for DO. The manuscript discussed the methodology and results from a modeling study carried out using SWAT model along with recently available datasets. Before analyzing the water 
quality benefits of different BMPs, and estimating the DO compliance of the river in each river reach, the modeled water quality results were compared with the observed counterparts where possible. The results obtained from the study suggests the following conclusions: (1) The water quality results obtained from SWAT model correspond to the quality of input datasets used; (2) The modeled water quality results were found adequate to use them for analyzing various scenario trials; (3) Although the agricultural BMPs implemented in the watershed along with the stringent water quality standards have improved DO in the tidal sections of river, the non-tidal section is suffering from poor DO because of increased point source discharges, which need to be mitigated; (4) This study pointed out that point source pollution is a present concern (for non-tidal section of river) in the watershed; (5) Binomial method of analyzing water quality trends is found to be a reliable method.

\section{ACKNOWLEDGEMENT}

The streamflow data were provided by the International Boundary and Water Commission (IBWC). Water quality data were provided by Texas Commission on Environmental Quality (TCEQ). Ronnie Ramirez and Andy Garza of Texas State Soil and Water Conservation Board (TSSWCB) helped to get data on land management practices and Best Management Practices (BMPs) adopted by landowners in the watershed. The members of the Arroyo Colorado watershed partnership provided valuable comments and suggestions during the course of the study. Many sincere thanks to all of those who helped to complete this project.

\section{REFERENCES}

[1]. Texas Natural Resource Conservation Commission (TNRCC) (presently Texas Commission on Environmental Quality), 1997. Chapter 307 - Texas Surface Water Quality Standards, No. 307.1-307.10.

[2]. Rains, T.H., and Miranda, R.M. (2002). "Simulation of Flow and Water Quality of the Arroyo Colorado, Texas, 1989-99". United States Geological Survey-Water Resources Investigations Report, No: 02-4110.

[3]. Rosenthal, W., and Garza, A. (2007). "SWAT Simulations of Nutrient Loadings in the Arroyo Colorado Watershed". In Proc. 2007 ASABE Annual International Meeting, Minneapolis, Minnesota (paper No. 072031).

[4]. Arroyo Colorado Watershed Protection Plan, 2007. A watershed protection plan for the Arroyo Colorado: Phase I, 2007. A Report of the Arroyo Colorado Watershed Partnership and Texas Sea Grant Pursuant to 2003 USEPA Clean Water Act Act Section 319 (h) Grant Awarded through Texas Commission on Environmental Quality Contract Agreement 583-4-65618.

[5]. Soil Survey Staff.2008. Spatial and tabular data of the Soil Survey for Cameron, Hidalgo and Willacy counties, TX, USA. United States Department of Agriculture, Natural Resources Conservation Service. Available URL: "http://soildatamartnrcs.usda.gov/" Fort Worth, TX.

[6]. National Oceanic and Atmospheric Administration. (1996). Climatological data, Texas, annual summary:
Asheville, NC, Vol. 101, No. 13, U.S. Dept. of Commerce, Washington, DC.

[7]. Arnold, J.G., Allen, P.M., and Bernhardt, G. (1993). “A comprehensive surface-groundwater flow model". Journal of Hydrology, 142, 47-69.

[8]. Gassman, P.W., Reyes, M. R., Green, C. H., and Arnold, J. G. (2007). "The soil and water assessment tool: Historical development, applications and future research directions." Trans. ASABE, 50(4), 1211-1250.

[9]. Neitsch, S.L., Arnold, J.G., Kiniry, J.R., Srinivasan, R. and Williams, J.R. (2004). "Soil and Water Assessment Tool-Version 2005-User's Manual”, Temple, TX, USA. [10]. [18]. http://swat.tamu.edu/

[11]. Runkel, R.L., Crawford, C.G., and Cohn, T.A., 2004, Load Estimator (LOADEST): A FORTRAN Program for Estimating Constituent Loads in Streams and Rivers: U.S. Geological Survey Techniques and Methods Book 4, Chapter A5, 69 p.

[12]. Stichler, C., and McFarland, M. (2001). "Crop nutrient needs in south and southwest Texas." B-6053, 04-01, Texas Agricultural Extension Service, Texas A\&M Univ. System, College Station, TX.

[13]. Trostle, C., and Porter, P. (2001). Common concerns in west Texas sunflower production and ways to solve them, Texas Agricultural Extension Service, Texas A\&M Univ. System, College Station, TX.

[14]. Stichler, C., McFarland, M., and Coffman, C. (2008). "Irrigated and dry land grain sorghum production: South and southwest Texas." 5M-5-97, New AGR1, Texas Agricultural Extension Service, Texas A\&M Univ. System, College Station, TX.

[15]. Vegetable Team Production. (2008). Onion production guide, Cooperative Extension Service, College of Agricultural and Environmental Sciences, Univ. of Georgia, Athens, GA.

[16]. Wiedenfeld, B., and Enciso, J. (2008). "Sugarcane responses to irrigation and nitrogen in semiarid south Texas.” Agron. J., 100(3), 665-671.

[17]. Wiedenfeld, B., and Sauls, J. (2008). "Long term fertilization effects on 'Rio Red' grapefruit yield and shape on a heavy textured calcareous soil." Scientia Horticulturae, 118(2), 149-154.

[18]. Cruces L. (2003). "Drought strategies for Cotton”. Cooperative Extension Service, Circular 582, College of Agriculture and Home Economics, New Mexico State University.

[19]. Fipps, G. (2005). Potential water savings in irrigated agriculture for the Rio Grande planning region, Irrigation Technology Center, Dept. of Biological and Agricultural Engineering, Texas A\&M Univ. System, College Station, TX.

[20]. Fipps, G., and Pope, C. (1998). "Implementation of a district management system in the Lower Rio Grande Valley of Texas." Proc. 14th Technical Conf. on Contemporary Challenges in Irrigation and Drainage, U.S. Committee on Irrigation and Drainage, Phoenix.

[21]. Fipps, G., and Pope, C. (1999). Irrigation district efficiencies and potential water savings in the Lower Rio Grande Valley of Texas, Texas A\&M Univ., College Station, TX. 
[22]. Kannan, N., Jeong, J., and Srinivasan, R. (2011). "Hydrologic Modeling of a Canal-Irrigated Agricultural Watershed with Irrigation Best Management Practices: Case Study." J. Hydrol. Eng., 16(9), 746-757.

[23]. Texas Water Development Board (TWDB). (2005). "Water conservation best management practices (BMP) guide for agriculture in Texas." Based on the Agricultural BMPs contained in Rep. 362, Water Conservation Implementation Task Force, Austin, TX.

[24]. Schwab GO, Fangmeier DD, Elliot WJ (1995) Soil and water management systems. Wiley, New Jersey, pp $108-111$.

[25]. United States Environmental Protection Agency (USEPA). 1988. Design Manual-Constructed Wetlands and Aquatic Plant Systems for Municipal Wastewater Treatment. Center for Environmental Research Information, Cincinati, OH, USA. Report No EPA/625/1-88/022.

[26]. Kannan, N. 2012. SWAT modeling of Arroyo Colorado Watershed, Texas Water Resources Institute, Report No. TR-426, June 2012.

[27]. Abbaspour, K, 2012. SWAT-CUP 2012: SWAT Calibration and Uncertainty Programs - A User Manual EAWAG: Swiss Federal Institute of Aquatic Science and Technology, Zurich, Switzerland.

\section{BIOGRAPHIES}

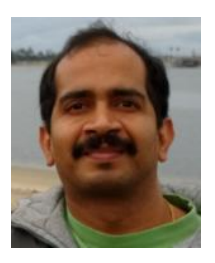

Dr. Narayanan Kannan is a scientist with expertise in assessment of large-scale water quality and quantity issues. Presently he is analyzing water and energy usage in animal production.

Ms. Nina Omani is a graduate student pursuing Ph.D. in hydrology at Texas A\&M University, College Station, USA.

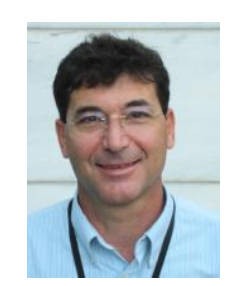

Mr. Roger Miranda is a graduate student pursuing Ph.D. in Public Affairs at the University of Texas at Austin, TX, USA. 